Тийна ЛИННАС, Хелбе НУТТ,

Светлана ВИЛЬДЕ, О. КИРРЕТ

\title{
МЕТОДЫ АФФИННОЙ ХРОМАТОГРАФИИ АНТИТЕЛ \\ И ИЗОЭЛЕКТРИЧЕСКОГО ФОКУСИРОВАНИЯ \\ В ИССЛЕДОВАНИИ ИММУННЫХ СДВИГОВ \\ ПРИ ЗАБОЛЕВАНИЯХ ПОДЖЕЛУДОЧНОЙ ЖЕЛЕЗЫ
}

\begin{abstract}
Введение
Заболевания поджелудочной железы занимают одно из первых мест в патологии желудочно-кишечного тракта. Диагностика их сложна, и ряд вопросов, связанных с патогенезом и диагностикой этих заболеваний, не может быть разрешен без использования иммунологических и биохимических методов. При острых и хронических поражениях поджелудочной железы в крови больных обнаружены циркулирующие антитела $\left[{ }^{1-8}\right]$. С целью их количественного подсчета нами была разработана на основе иммуносорбентного метода Гурвича $\left[{ }^{9,10}\right]$ методика определения антител против ткани поджелудочной железы $\left.{ }^{4}\right]$ с помощью аффинной хроматографии. Были исследованы разные сорбенты, а также наряду с цельным экстрактом использованы специфические ферменты для определения антител против этих же ферментов.

Поскольку вышеупомянутый метод довольно трудоемок, параллельно был испытан и новый - метод изоэлектрического фокусирования в гелевых пластинках из полиакриламида с амфолиновыми носителями для определения различных фаз панкреатита.
\end{abstract}

\section{Материал и методика}

Исследовали шесть сывороток кроликов, иммунизированных ферментами и тканевыми антигенами поджелудочной железы. В качестве специфических ферментных антигенов использовали кристаллические препараты бычьей $\alpha$-амилазы, химотрипсиногена (фирмы «Serva»), трипсина, химотрипсина (фирмы «Spofa») . и липазы поджелудочной железы свиньи (фирмы «Serva»). Для получения цельного экстракта поджелудочной железы была изготовлена суспензия ткани в $0,25 \%$-ном растворе сахарозы ( $\mathrm{pH} \mathrm{8,0),} \mathrm{которую} \mathrm{центрифуги-}$ ровали при 20000 об/мин в течение 40 мин, чтобы освободиться от ядер и митохондрий поджелудочной железы. Концентрацию. белка супернатанта определяли с помощью биуретовой реакции. Она составляла $20-30 \mathrm{мг/мл.}$

Кроликов иммунизировали двумя способами.

1. Одновременно с адъювантом Фрейнда вводили по $4-8$ мг чистого белка в спинку животного 3-4 раза с трехнедельными интервалами, 
2. Внутривенно вводили по 4 мг белка в течение трех дней, затем следовал трехдневный перерыв с последующим введением 8 мг бел́ла в течение трех дней два раза подряд. Последний раз антиген вводили внутримышечно вместе с адъювантом Фрейнда. Через семь дней после последней инъекции у кроликов проверяли титр антител реакцией связывания комплемента по Иоффе и реакцией преципитации по Оухтерлони.

Кроме того, обследовали сыворотки 29 больных панкреатитом ч 19 больных раком поджелудочной железы. Согласно клиническим и лабораторным показателям, у всех больных панкреатитом (20.мужчин и 9 женщин в возрасте $30-76$ лет) была острая фаза заболевания. У большинства из них изменения поджелудочной железы были обнаружены при эндоскопической холецистопанкреатографии. У всех больных раком поджелудочной железы (8 мужчин и 11 женщин в возрасте $36-80$ лет) диагноз был гистологически подтвержден при лапаротомии.

В качестве сорбентов при хроматографии использовали сферон, АН-сефарозу, цианбромагарозу и синтетические гидрогели «Сорсилен» и «Инсолмер» (ЧССР).

Активация сферона 2-амино-4,6-дихлортриазином. 1 г сферона активировали в 20 мл раствора $\mathrm{NaOH}$ (от 1 до 3 н.) 15 мин. Затем раствор $\mathrm{NaOH}$ удаляли и к продукту добавляли 50 мл смеси из $2 \%$-ного раствора 2-амино-4,6-дихлортриазина и ксилолдиоксана $(1: 1)$. Реакция протекала при комнатной температуре в течение 4 ч. Затем продукт промывали смесью вода-диоксан-уксусная кислота $(1: 1: 1)$ с водой и ацетоном, высушивали в вакууме. Элементный состав $(\mathrm{H}, \mathrm{C}, \mathrm{N})$ продукта реакции определяли на автоматическом анализаторе «Hewlett Packard» (СШӒ) и концентрацию хлоридов потенциометром методом титрования.

Связывание антигенов на полимерный носитель «Инсолмер». К активированному глутаральдегидом полимеру добавляли 2 мл экстракта поджелудочной железы. Связывание проводили вं 5 мл фосфатного буфера при рН 7,0 в течение 3 ч при комнатной температуре. После связывания носитель промывали соляным раствором (100 мл) и оставляли в фосфатном буфере при рН 7,0.

Связывание антигенов на полимерный носитель «Сорсилен». На 100 мг активированного глутаральдегидом полиэфира прибавляли 4 мл экстракта поджелудочной железы. Связывание проводили в 20 мл буфера Мак-Ильвейна при $\mathrm{pH} 7,0$ в течение 2 ч при комнатной температуре и в присутствии 6 мл $25 \%$-ного раствора глутаральдегида. После связывания полиэфир промывали буфером Мак-Ильвейна и оставляли в нем. Количество антител к ферментам ( $\alpha$-амилазе, липазе и трипсину) и к цельному экстракту поджелудочной железы определяли в колюнке $0,9 \times 5,0$ см, наполненной агарозой, активированной цианбромом и обработанной соответствующим ферментом (50 мг). Для определения количества антител иммунную сыворотку или сыворотку больного вводили в колонку с иммуносорбентом после их 15-минутной инкубации трис-HCl-буфером $(0,2 \mathrm{M}, \mathrm{pH} 8,0)$, содержащим $0,5 \mathrm{M}$ раствора хлористого натрия. Этим же буфером сначала вымывали неспецифические антитела и затем глицин-НCl-буфером $(0,2 \mathrm{M}$, $\mathrm{pH} 2,8)$, содержащим $0,5 \mathrm{M}$ хлористого натрия, - специфические антитела. Количество белка определяли при абсорбции на 280 нм спектрофотометром \&Spektromom» (BНP). Фракции, которые содержали специфические белки, собирали, лиофилизировали и получали таким образом из иммунных сыворотоқ специфические антитела к $\alpha$-амилазе, трипсину и липазе, 


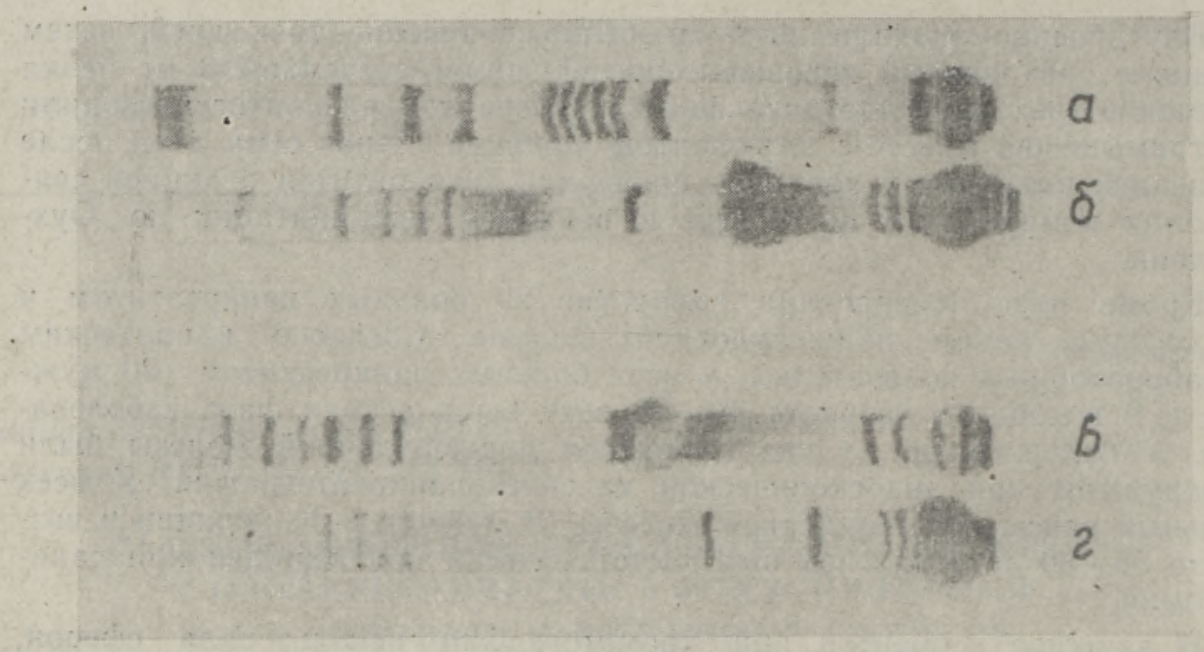

Сыворотки практически здорового человека $(a)$, больного хроническим панкреатитом в стадии обострения (б), больного в активной фазе панкреатита на 2-й день заболевания (в) и больного раком поджелудочной железы (2), идентифицированные методом изоэлектрического фокусирования в гелевых пластинках нз полиакриламида с амфолиновыми носителями при $\mathrm{pH} 4-9$.

Изоэлектрическое фокусирование - отличный метод для анализа энзимов, гормонов и других протеинов. Градиент $\mathrm{pH}$ образуется в поддерживающей среде при воздействии на амфолины электрического тока. Когда протеин попадает в пределы градиента $\mathrm{pH}$, он мигрирует под влиянием электрического тока до позиции его рI и останавливается там. Мы использовали амфолины-носители в пределах рН 4-9. Гель был образован из акриламида $(3,9$ г) с метилен-бис-акриламидом $(0,13$ г) в качестве сшивающего агента, к которому добавляли 4 мл амфолина в пределах рН 4,2-9,5; 5,95 мл глицерола и 0,15 мл $\mathrm{N}, \mathrm{N}, \mathrm{N}, \mathrm{N}$-тетраметилэтилендиамина и доливали дистиллированную воду до 60 мл. Смесь дегазировали в течение 4 мин под вакуумом, затем добавляли 0,004 г персульфата аммония, растворенного в 2 мл раствора. Раствор сразу пипетировали в гелевую прессформу для полимеризации. Пробы сыворотки больных (10 мкл) на кусочках фильтровальной бумаги помещали в катодную зону гелевой пластины из полиакриламида.

Изоэлектрическое фокусирование проводили на приборе «Multiphor LKB-2117» (Швеция) при $10 \mathrm{~B}, 1200 \mathrm{BT}$ и $4^{\circ} \mathrm{C}$. Анодным электролитом служила $0,1 \mathrm{M} \mathrm{H}_{3} \mathrm{PO}_{4}$ и катодным электролитом $-0,1 \mathrm{M} \mathrm{NaOH}$. Фокусированный гель погружали непосредственно в фиксированный раствор на 1 ч, затем вынимали и хранили между двумя листамн целлофана.

\section{Результаты и обсуждение}

При пропускании через колонки со сферон-трипсином иммунных сывороток к трипсину, $\alpha$-амилазе, химотрипсину, химотрипсиногену, липазе, с трипсином связывались в основном противотрипсиновые антитела $(1,52 \mathrm{mr} /$ мл). Однако при использовании колонок с АН-сефарозой-липазой те же самые сыворотки реагировали не только с противолипазной сывороткой $(4,40$ мг/мл), но и с противоамилазной $(6,80 \mathrm{мг} / \mathrm{мл})$, противохимотрипсиновой $(2,88 \mathrm{mг} / \mathrm{мл})$ и противохимотрипсиногенной $(1,98$ мг/мл). Видимо, липаза, которой иммунизиро- 
вали кроликов, была не чистой, а содержала еще соответствующие ферменты.

При пропускании сывороток через колонку с цианбромагарозой, связанной с цельным экстрактом, было обнаружено, что среднее количество антител у больных панкреатитом (в основном хроническим в стадии обострения) и у больных раком поджелудочной железы колебалось в пределах $3,56-2,95$ и $3,86-5,56$ мг/мл соответственно, т. е. у тех и других больных было приблизительно одинаковым.

Так как ранее [ $\left.{ }^{7}\right]$ при использовании в качестве сорбента сферона нами было обнаружено повышенное количество антител у двух больных раком поджелудочной железы, мы провели дополнительное исследование сывороток больных обеих групп на колонках с антигенсодержащими сорсиленом и инсолмером. Это исследование подтвердило отсутствие существенных различий в данных. У тех же больных были обнаружены антитела к $\alpha$-амилазе $(2-3$ мг/мл), трипсину $(1-1,95$ мг/мл) и липазе $(1-5$ мг/мл).

Следовательно, количественный метод определения антител к специфическим ферментам поджелудочной железы весьма эффективен в случае активной фазы панкреатита и в случае иммунодиагностики этого заболевания.

При изоэлектрическом фокусировании сывороточных белков здоровых лиц, больных в активной фазе панкреатита и больных раком поджелудочной железы получены разные картины линий в полиакриламидном геле с амфолином (см. рисунок).

В случае фокусирования наряду со специфическими ферментными растворами и цельным экстрактом поджелудочной железы сывороток крови и специфических антител прослеживалось сходство получаемых линий с линиями больных панкреатитом и раком поджелудочной железы. Эти данные совпадают с результатами наших предыдущих исследований [4, 7], в которых реакцией преципитации по Оухтерлони и реакцией связывания комплемента по Иоффе было обнаружено, что в активной фазе панкреатита и в IV стадии рака поджелудочной железы в сыворотках крови у многих больных имеются субклеточные (микросомальные, рибосомальные, цитоплазматические) антигены и специфические ферменты ( $\alpha$-амилаза, трипсин, липаза) поджелудочной железы.

Следовательно, метод изоэлектрического фокусирования, уже с успехом применяемый для диагностики болезней печени и некоторых других органов, может быть полезен и при диагностике панкреатита. С его помощью можно легко разделять различные ферменты и другие антигены поджелудочной железы, а также антитела в сыворотках крови больных и на этом основании диагностировать различные фазы панкреатита.

\section{Выводы}

1. Определением количества сывороточных антител к ткани подж́леудочной железы и ее специфическим ферментам можно выявить активную фазу панкреатита.

2. Методом изоэлектрического фокусирования достигнута возможность разделения различных содержащихся в сыворотке крови больных панкреатитом антигенов и ферментов поджелудочной железы, что позволяет отличать стадию обострения этого заболевания от стадии ремиссии. 
1. Бугримов В. Г. Изучение антипанкреатических антител методом связывания антиглобулина при острых и хронических панкреатитах. - Терапевт. архив, 1968, № $10,85-87$.

2. Бялик Я. $P$. Холецистопанкреатиты. (Экспериментально-клиническое исследование). Автореф. докт. дис. Тарту, 1968.

3. Геллер Л. И., Казитирчик А. П. Клинико-иммунологические сопоставления при хроническом панкреатите. - Терапевт. архив, 1971, № 2, 70-76.

4. Линнас T., Микельсаар $P$., Нутт X., Киррет О. Гликольметакрилатные гели как носители для аффинной хроматографии антнтел. - Изв. АН ЭССР. Хим., 1978, 27, № 1, 46-48.

5. Нутт X. $P$. Значение гуморальных и клеточных иммунологических реакций при острой и хронической фазах панкреатита. Канд. дис. Тарту, 1981.

6. Нутт X. P. Значение гуморальных и клеточных иммунологических реакций при острых и хронических панкреатитах. - В кн.: Механизмы регуляции деятельности и функциональная диагностика болезней поджелудочной железы. Тарту, 1979, 94-108.

7. Нутт X. P., Линнас T. П. Количество циркулирующих антител при панкреатите. - Уч. зап. Тартуск. ун-та, 1979, № 485, 101-105.

8. Сидоров K. А., Митропольский А. Н. Иммунопатологические изменения у больных хроническим панкреатитом и сахарным диабетом. - Терапевт. архив, 1968, № 1, 98-103.

9. Гурвич А. Е., Капнер Р. Б., Незлин Р. С. Выделение чистых антител при помощи фиксированных на целлюлозе антител и изучение их свойств. - Биохимия, 1952, 24, № $1,144-147$.

10. Гурвич A. E., Кузовлева $O$. Б., Туманова $A . E$. Применение иммуносорбентов в виде суспенат для определения абсолютного содержания антител. - Биохимия, 1962,27, № $2,246-248$.

\author{
Ннститут химии \\ Академии наук Эстонской ССР \\ Поступила в редакцию \\ 28/XII 1983
}

\begin{abstract}
Институт общей и молекулярной патологии при Тартуском государственном университете
\end{abstract}

Tiina LINNAS, Helbe NUTT,

Svetlana VILDE, O. KIRRET

\title{
AFIINSUS-KROMATOGRAAFILINE JA ISOELEKTRILINE MEETOD ANTIKEHADE IMMUUNSUSNIHETE UURIMISEKS PANKREATIIDI KORRAL
}

Artiklis on esitatud afiinsus-kromatograafiline ja uus, isoelektrilise fokuseerimisz meetod, millede abil on vōimalik lahutada pankrease antigeene ja fermente ning selle põhjal diagnoosida pankreatiidi eri faase.

Tiina LINNAS, Helbe NUTT,

Svetlana VILDE, O. KIRRET

\section{THE METHODS OF AFFINITY CHROMATOGRAPHY OF ANTIBODIES AND ISOELECTRIC FOCUSING FOR STUDYING IMMUNOLOGICAL SHIFTS IN THE CASE OF PANCREATITIS}

The article reports the methods of affinity chromatognaphy for determination of antibodies to pancreas and isoelectric focusing which enable us to separate antigens and proteins of the pancreas as well as to diagnose pancreatitis at different phases, 